\title{
Analysing the Motives Sustaining a Foreign Investment Resurgence in Australian Coal
}

\author{
Jason West $t^{1}$ \\ ${ }^{1}$ Griffith Business School, Griffith University, Australia \\ Correspondence: Jason West, Department of Accounting, Finance and Economics, Griffith Business School, \\ Griffith University, 170 Kessels Rd, Nathan QLD, 4111, Australia. Tel: 61-737-354-272. E-mail: \\ j.west@griffith.edu.au
}

Received: February 9, 2012 Accepted: March 19, 2012 Online Published: May 16, 2012

doi:10.5539/ijbm.v7n10p11 URL: http://dx.doi.org/ijbm.v7n10p11

\begin{abstract}
The Australian coal industry has frequently been described as being in a state of 'profitless prosperity' referring to the continued investment in low margin mining activities by foreign companies with motives other than profit. Prior research showed that through the use of government investment concessions, foreign trading companies created an oversupply of seaborne coal to depress prices at the cost of profitability. This study shows that such 'quasi-integration' via concessional funding arrangements is no longer a primary strategy employed by foreign trading companies or governments and finds no evidence of such companies securing coal at below average prices. This study also finds no clear evidence of foreign trading companies using their implicit information advantage as equity investors to secure coal at favourable prices during contract negotiations. The study also examines the investment behaviour of new entrants in the market to highlight the strategic differences between foreign investors.
\end{abstract}

Keywords: coal, energy, foreign investment, government subsidies

\section{Introduction}

The volume of coal produced in Australia and made available for export is expected to rise across all regions in the next 10-15 years. This is due to increased global demand for raw materials needed for energy and steel particularly in Asia, and the reversal of China as a coal exporting nation to become a major coal importer in 2010 while consumption in the other major import centres of Japan, South Korea and Europe has remained largely static. The liquidity of seaborne coal supply has greatly increased in the past 10 years with the establishment of standardised contracts and a common coal trading platform in Australia for thermal coal as well as a recent shift from annual contract negotiations to quarterly negotiations for coking coal. The continued growth in coal production within a physically constrained supply chain for export to consumers has seen foreign ownership of Australian coal mining grow from 43 percent in 1997 to around 75 percent in 2010 and profitability levels steadily rise over the same period.

Given Japan's dominant position in the Asia-Pacific regional coal market and the relatively low profitability of Australia's coal industry during the 1990s it was shown by Colley (1997) that the influence of the Japanese trading companies using concessional funding from Japanese Government agencies to invest in major coal assets created an oversupply in the market to depress coal supply contract prices. Koerner et al. (1995), Koerner (1998) and Swan et al. (1999) showed that other benefits from being a minority equity partner in producing mines such as greater information on marginal production costs and capital returns also assists Japanese trading companies during contract price negotiations. Hedonic regression was used to investigate behaviour in annual coking coal negotiations and econometric evidence showed inefficient pricing consistently occurred in the coking coal market due to information advantages, once contracted coal prices were adjusted for differences in quality.

D'Cruz (1983) examined the impact of so-called quasi-integration resulting from Japanese trading companies' establishment of long-term purchasing agreements for coking coal supplies on the price and volumes purchased from producers over the 1970s. The hypothesis was that quasi-integration would assuage the influence of market power during cyclical phases of supply and demand imbalance. The research demonstrated that during periods of coal producer dominance (during periods of steel production growth), coking coal producers directly linked with Japanese consumers would receive lower prices and experience greater volume stability than independent coal 
producers, thereby benefiting from quasi-integration. Conversely during periods of industry downturns quasi-integrated coal producer contract prices were shown to be higher than for an independent coal producer, while also achieving superior offtake volumes. The results of this research also concluded that any positive effects of quasi-integration on price were minor compared with the detrimental effects of price discrimination practised by the Japanese firms in the Pacific coal market. Colley (1997) updated this thesis to show the existence of oversupply was driven by low profitability targets of Japanese trading companies across both thermal and coking coal markets over the period 1986-1996.

Despite the positive forecasts that the industry experienced over the period 1975-1997 the above research showed that average profitability and return on capital in the coal mining industry were much lower than expected. However since 1998 and more noticeably during the period 2005-2010, coal production and profitability have both grown at a much higher level than expected. The characteristics of the mining industry globally and particularly in Australia have changed significantly over this period due to a surge in commodities demand from large emerging economies, and it is claimed that this has in turn altered the investment behaviour of foreign trading companies looking to acquire ownership interest in Australian mining assets.

The purpose of this study is to investigate if quasi-integration via concessional funding arrangements from government agencies is still a strategy employed by Japanese trading companies and if so, is such a strategy achieving below average prices, volume stability and information advantages for use in contract price negotiation. Furthermore this study will also investigate whether such strategies continue to be employed at the expense of profitability and capital return when measured against peer mining companies in Australia. Finally this analysis will examine the investment behaviour of new entrants in the market from South Korea, China and India to determine if the above advantages serve as the main motive behind their acquisition strategies, or if other reasons such as the security of supply are driving foreign investment in coal assets.

\section{Preliminaries}

\subsection{Growth Projections}

The majority of current and projected Australian coal production growth is in thermal coal. In 2010 thermal coal represented 56 percent of total output and expectations are that this proportion will rise to at least 59 percent by 2020. In 2010 there was 208 million tonnes of thermal coal produced for both domestic consumption and for export, and total production is expected to grow to 335 million tonnes by 2020. Metallurgical or coking coal production in 2010 was 165 million tonnes with production growth expected to surge to 229 million tonnes by 2020. Growth in coking coal production over this period will be driven primarily by rising exports of hard coking coal (HCC) and coal suitable for pulverised coal injection (PCI), with more modest growth in semi-soft coking coal. These projections are provided in Willacy et al. (2010).

Queensland accounted for 57 percent of Australian black coal production in 2010 with over half of the state's output being metallurgical coal sold on the export market. New South Wales accounted for 40 percent of Australian black coal production in 2010, the majority of which is thermal coal sold for export. Relatively small volumes of thermal coal are produced in South Australia and Western Australia driven by local power station demand.

The Bowen Basin in Queensland is the largest coal producing basin in Australia, accounting for 49 percent of total output in 2010. The second largest producing area is the Sydney Basin in New South Wales which accounted for 38 percent of the total. Production from both basins is expected to rise though to 2020 but their respective share of production is likely to fall as infrastructure developments drive exports from newly developing areas. Production of mostly thermal coal with some coking coal from the Surat Basin in Queensland and the Gunnedah Basin in New South Wales is expected to increase strongly.

The supply chain is expected to largely keep pace with the current rate of expansion. Australian port capacity for coal exports is expected to increase from 348Mtpa in 2010 to 634Mtpa by 2020 . Total rail capacity for coal is expected to increase from 375Mtpa in 2010 to 684Mtpa by 2020, meaning that rail capacity is likely to lead port capacity on most systems over the next ten years, with some exceptions.

The utilisation of Australia's export infrastructure, as indicated by the ratio of actual exports over nominal port capacity remain at levels of around 80-85 percent of nominal port capacity, so the above figures are indicative of the upper limit of expectations. Infrastructure will be the main constraint on export volumes for the next 10-15 years, see Willacy et.al (2010). Nevertheless the expected growth is driving high rates of investment in coal mining operations in Queensland and New South Wales with a total net capital expenditure of US\$6.6bn per annum increasing to over US\$10.4bn per annum over the 2007-2010 period, see Australian Bureau of Statistics 
(2010).

New grants for coal tenements in Australia have more than doubled over the period 2007-2010. New lease areas were dominated by exploration permits in Queensland, mostly in the well-established Bowen Basin due to the availability of high-quality and therefore high profit margin hard coking coal. Tenements with deeper coal seams that require more difficult extraction techniques have recently been shown to be profitable to mine, particularly with the recent advancement in underground mining technologies. Emerging coal basins such as the Galilee and Surat in Queensland are also attracting considerable exploration interest, see Willacy et.al (2010) although they contain lower margin thermal coal.

The rapid growth of investment has continued despite increases in state-based royalties and uncertainty surrounding a resource rent tax anticipated to be legislated by the Australian Government by 2012. The resource tax will apply to most coal mines and will impose taxes of around 30 percent on the export value of the coal after deducting an amount equivalent to the long-term bond rate plus 7 percent on the book value of the asset. This is expected to have some impact on the capital rationing strategies employed by global resource companies and the Asian trading companies with mine values decreasing by 20-30 percent on an NPV basis.

Mining companies in Australia are subject to a range of taxes which vary by State. Where the ownership of coal is vested in the State, the relevant State government receives a royalty payment for the right to mine that coal. The current New South Wales State royalty regime has been in place since 2004. A differential ad valorem royalty rate is imposed on mines based on mining method. In 2009 the royalty rates were increased to 6.2 percent for deep (greater than $400 \mathrm{~m}$ ) underground mines, 7.2 percent for other underground mines and 8.2 percent for open cut mines. The royalty charge is applied to the value of production (total revenue less allowable deductions) of the coal. Allowable deductions are limited to beneficiation costs and the various coal industry levies (detailed below). A fixed sum for coal beneficiation costs is deductible, according to a schedule dependent on the degree of beneficiation. Prior to 2009 the royalty rates by mine type were 5, 6 and 7 percent respectively with transport and port costs included as allowable deductions.

In Queensland a two tier ad valorem royalty regime for export coal was introduced in 2008. For the first A $\$ 100$ of the export price a 7 percent levy is charged while export coal sold above A $\$ 100$ per tonne attracts a levy of 10 percent. Domestic coal is charged a uniform royalty rate of 7 percent. The royalty charge is applied to the value of production (total revenue less allowable deductions) of the coal. Allowable deductions are port charges, despatch and demurrage, research and development costs and long service leave levies. Freight costs and marketing costs are non-deductible.

Mining companies in Australia are also subject to a number of other relatively minor levies such as the coal research levy used to fund coal industry research in areas such as safety standards and environmental issues, the mine safety levy used to fund State Government safety functions in relation to mining, as well as the mine subsidence levy and the mines rescue levy. The imposition of a number of royalties, levies and a resource tax appear to have had little impact on the investment growth in Australian coal mining.

\subsection{Industry Structure and Japanese Investment}

The Australian coal industry exhibits a high degree of foreign ownership with over 75 percent of production generated from foreign-owned companies in 2009. The concentration of coal production is high and has been dominated by four major companies who account for 65 percent of exports by value. But actual ownership within the industry continues to be diverse as mine-sites are typically incorporated under a variety of joint venture agreements among domestic operators and foreign investors. A useful measure of market concentration and therefore competition is the Herfindahl-Hirschman Index (HHI), defined as the sum of the squares of the market shares of all firms within an industry, where the market shares are expressed as fractions. The result is proportional to the average market share weighted by market share which means that it ranges from 0 to 1 . For the Australian coal industry the HHI measure was approximately 8.882 percent in 2010 which has fallen from 10.317 percent in 2005 , indicating very little concentration among producers.

There is also a significant level of ownership volatility in the industry with a high rate of merger and acquisition activity, especially concerning coal-exploration companies who are selling assets that have been extensively surveyed and are ready for mine development and production.

Of the foreign investors the Japanese trading companies constituted 19.3 percent of total production in 2010, which translates into a total share of 14.5 percent across the entire industry. This share has remained relatively static since 1997 meaning that Japanese investment in the industry, along with other investors and developers, has grown in absolute terms at around 5.7 percent per annum. The Australia-Japan producer-consumer coal trade 
relationship developed over several decades which stems from Japan's strategic need to secure a long-term supply of raw materials. An extensive history is provided in Barnett (1994). However prior to 1997 growth was relatively weak in the coal sector, with seaborne coal prices, hence profitability, at very low levels compared with other industries, see Barnett (1994).

Colley (1997) noted that the distinction in capital formation of the parties in the Australia and Japan coal trade is vital for understanding the reasons behind the oversupply and depressed prices during the 1990s. Colley claimed that quasi-integration only occurs in one direction with Japanese-based coal consumers taking minority equity or joint venture stakes in Australian mines, while the opposite is unlikely to occur. Japanese shareholders display strong patterns of cross-shareholdings, see Koerner (1998) which have persisted over the period 1997-2010 as opposed to the diffuse ownership structure of most Australian firms. Furthermore the fragmented and volatile ownership structure of the Australian industry lacks 'coherence' relative to the tightly coordinated and stable ownership structure of Japanese trading companies.

These general conditions are similar to the conditions in the 1990s when Japanese investment in the Australian mining sector supported via loan concessions from the main Japanese export agencies was at a peak, McIntosh Baring (1993). The Colley (1997) study showed that excess capacity was a feature of world coal supply and demand conditions over the ten year period to 1995 . However such analysis ignores the spread of coal qualities across world production, especially as Japan is a buyer of high quality coal with strict specification limits on levels of ash, sulphur and nitrogen in thermal coal, and volatile matter and sulphur in coking coal. Demand and supply conditions for Japanese consumers have in fact largely been in balance from 1995 to 2009, with some excess capacity leading to slightly lower prices evident during the financial crisis in 2008. This is illustrated in Table 1.

Table 1. Excess capacity in seaborne hard coal to Japan, Mtpa

\begin{tabular}{rrrrccc}
\hline \multicolumn{5}{c}{ Thermal Coal } & \multicolumn{3}{c}{ Coking Coal } \\
\hline & Supply & Demand & Excess Capacity & Supply & Demand & Excess Capacity \\
\hline 1995 & 57.8 & 58.9 & -1.1 & 57.6 & 54.1 & 3.5 \\
1996 & 62.8 & 59.9 & 2.9 & 56.7 & 53.8 & 2.9 \\
1997 & 69.9 & 66.6 & 3.3 & 55.8 & 53.5 & 2.3 \\
1998 & 75.0 & 65.1 & 9.9 & 54.9 & 53.2 & 1.7 \\
1999 & 82.3 & 68.0 & 14.3 & 53.9 & 52.0 & 1.9 \\
2000 & 93.2 & 93.6 & -0.4 & 52.8 & 52.8 & 0.0 \\
2001 & 99.0 & 98.7 & 0.3 & 53.0 & 52.1 & 0.9 \\
2002 & 96.6 & 102.9 & -6.3 & 51.5 & 51.4 & 0.1 \\
2003 & 98.9 & 108.7 & -9.8 & 49.2 & 50.7 & -1.5 \\
2004 & 100.9 & 103.0 & -2.1 & 61.3 & 49.9 & 11.4 \\
2005 & 104.9 & 99.5 & 5.4 & 56.5 & 54.2 & 2.3 \\
2006 & 107.7 & 105.0 & 2.7 & 57.7 & 52.7 & 5.0 \\
2007 & 118.9 & 114.0 & 4.9 & 58.2 & 57.6 & 0.6 \\
2008 & 115.6 & 112.8 & 2.8 & 57.4 & 60.7 & -3.3 \\
2009 & 114.0 & 109.1 & 4.9 & 59.5 & 54.3 & 5.2 \\
2010 & 115.0 & 109.1 & 5.9 & 58.0 & 60.1 & -2.1 \\
\hline
\end{tabular}

Source: IEA 2009.

Coal sold into the Japanese market usually attracts a premium to the benchmark price due to the greater limitations on quality specifications which requires greater processing. It remains feasible that global excess capacity depressed prices significantly in the 1990s but this excess has not persisted in the 15-year period beyond 1995. 


\section{The End of Profitless Prosperity}

The insights provided by Colley (1997), Koerner (1993) and Koerner (1998) concluded that that the process of quasi-integration of Japanese-based companies and the co-ordinated strategy behind it were a significant contributing factor to the poor profit performance of the Australian coal industry from 1986-96. The Colley study focussed on the co-ordinated set of activities between private Japanese companies and the Japanese Government to explain the effect of quasi-integration on profits from Australian coal mining. It demonstrated that the profit performance of these investments was poor over the period examined and, by corollary, so was the performance of other equity partners in the same projects. The study drew upon and emphasised the argument claimed in D'Cruz (1983) and Anderson (1987) that the coal trade between Japanese industry and some of its major suppliers exhibits the characteristics of so-called quasi-integration. Quasi-integration is referred to here as the existence of elements of vertical integration short of conventional vertical integration in that the degree of common ownership is less than a controlling interest. It was shown in Anderson (1987) and Colley (1997) and that the primary purpose behind this form of vertical integration is to achieve an oversupply of a particular resource in order to depress prices over an extended period of time.

It has been suggested that other motives and advantages for Japanese trading companies result from minority equity investment in coal mining operations. Dowling (1987) and Koerner (1998) show that greater knowledge of marginal production costs and capital returns gained from partial ownership in producing mines may be a contributing factor to create distortions in the seaborne coal market. The trading arms of the Japanese firms may make this knowledge available to their respective negotiating team who bargain with individual Australian producers on behalf of the consumption arm of their firm. Koerner (1998) demonstrated that this arrangement significantly contributed to the depressed prices for coking coal during the period 1988-1998. A key element of this study is to investigate whether this information advantage continues to create opportunities to distort the market.

Japanese general trading companies, also known as sogo shosha, have traditionally maintained strong links with government, Roehl (1983). The initial rationale for the trading companies' existence was as the developers and procurers of raw material for Japanese industry. However the notion of strong profit performance has been described as foreign to typical Japanese trading houses as they traditionally operate on very thin margins, in the order of a gross profit of rarely more than 3 percent. They are renowned for their low profitability despite significant diversity in balance sheet assets. A study by the Australia-Japan Economic Institute in 1996 ranked net profit after tax against the global trading volumes of each company to show that none of the nine largest Japanese trading houses achieved a net profit after tax of better than 0.35 percent of sales between 1989 and 1995, while the average was 0.1 percent, see Australia-Japan Economic Institute (1996).

Up to the late 1990s Japan's general trading houses traditionally made their money from high-volume, low-margin transactions in raw materials and commodities. However, these activities no longer offer much opportunity for growth, and the trading companies, especially the larger ones, appear to be investing in more profitable undertakings in manufacturing and infrastructure projects, and where possible mining projects.

In 1997 Japanese-based companies were a significant investor in the Australian coal mining industry (13 percent in 1993), but were rarely the majority or controlling owner of Australian coal mines. Through to 2010 the investment ratio has remained largely steady however many companies now hold a majority interest in Australian coal assets and in some circumstances the company is the sole owner and operator. Ownership proportions are clearly shifting from historical levels.

\subsection{Commodity Price Increases and Industry Effects}

The contract prices for both coking and thermal coal have increased markedly from 2006 to 2010 , primarily driven by net imports of each type of coal to China and India, both of who prior to 2008 were net exporters of coal. The commodities boom in 2008 triggered increases in average CIF import thermal coal prices by 77 percent and CIF import coking coal prices by 108 percent in Japan. Some contributing factors to the price spike include tight supply induced by a period of record consumption, infrastructure and production inefficiencies in major exporting countries and a halt to Chinese exports to meet domestic needs. The increase in thermal coal contract prices traded through the GlobalCOAL platform in 2005 as well as the switching of coking coal contract negotiations from annual to quarterly in 2010 has enhanced the liquidity of the global trade in these products. This has established a more efficient market-based pricing mechanism for exports of Australian coal. Figure 1 illustrates the free-on-board (FOB) price of both Queensland hard coking coal contracted to Japan and Newcastle thermal coal in 2010 US dollars. 


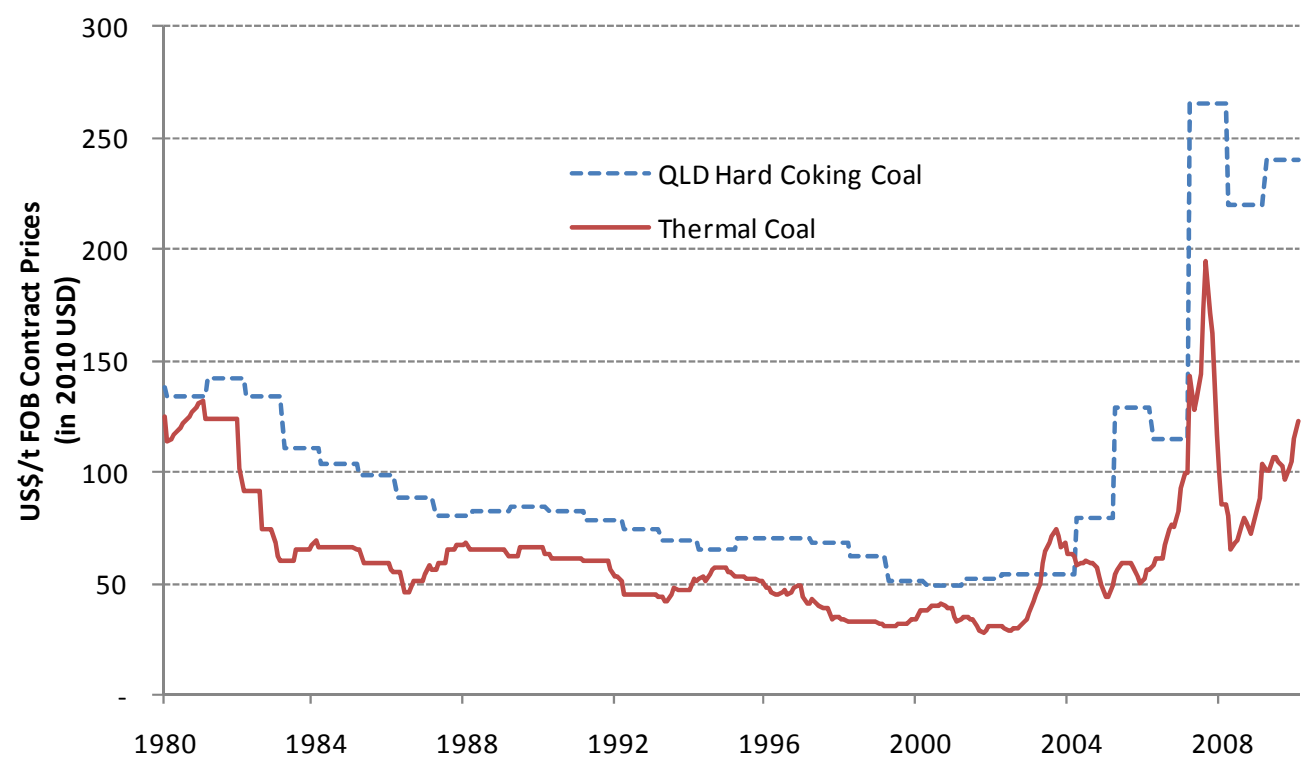

Figure 1. Queensland hard coking coal and Newcastle thermal coal price history 1980-2010 in 2010 US\$ Source: McCloskey Coal

Colley (1997) showed that the low coal prices experienced during the 1990s was driven jointly by Japanese Government and Japanese trading companies seeking to stimulate private investment in the Australian coal industry for the express purpose of enlarging supply and depressing contracted prices. This was conducted through the employment of concessional finance from a variety of agencies including the Japanese Ministry of International Trade and Industry (MITI), the Japan Development Bank, the Export-Import Bank of Japan, the Overseas Economic Cooperation Fund (OECF) and the New Energy and Industrial Technology Development Organisation (NEDO) which is a subsidiary of MITI.

After the promulgation of the Japan Bank for International Cooperation (JBIC) Act in April 1999 JBIC was established and assumed the operations of the Export-Import Bank of Japan and also those of the Overseas Economic Cooperation Fund (OECF). JBIC has assumed the formal role of facilitating Japanese trading company investment abroad.

The concessional financing strategy or kaihatsu yunso policy promulgated in the MITI White Paper in 1970 aimed to enable Japanese companies to place a larger reliance on direct investment in foreign ventures to augment long term supply agreements, take advantage of economies of scale and invest in large scale development projects and diversify investments across regions.

Concessional financing for coal mines provides both direct financing and guarantees for investment in existing or new mines and where necessary outright ownership of assets, plant and equipment at very low interest rates. Colley (1997) further showed that the profitability of Japanese companies investing in Australia as measured by earnings before interest and tax as a return on total funds employed (EBIT/TFE) was between 6.5 and 10 percent per annum, well below the benchmark average of 15 percent estimated by the Minerals Council of Australia.

Figure 2 illustrates JBIC global loan and investment commitment broken down in proportions to Australia, for global natural resource development and for global investment loans in natural resources from 1999-2009. Committed funds abroad has steadily increased over the ten year period and Japan's trading companies source a wider variety of raw materials from a growing number of regions. Japan's public sector commitment is quite significant at around $¥ 2,300$ bn from 2005 -08 with around $¥ 2,800$ bn committed in 2009 . This translates into an average commitment of around US\$25-33bn in natural resource investment and guarantees abroad. Much of this is committed to Asia and Africa. Figure 2 shows that a relatively minor amount has been committed to Australian-based projects from 1999-2009. This demonstrates that the strategy of quasi-integration investment practices deployed since 1999 for investment in Australian coal assets appears to have been discontinued, despite record coal price increases over the latter half of the period. Coal mining in particular has not received substantial JBIC investment loans for over a decade. 


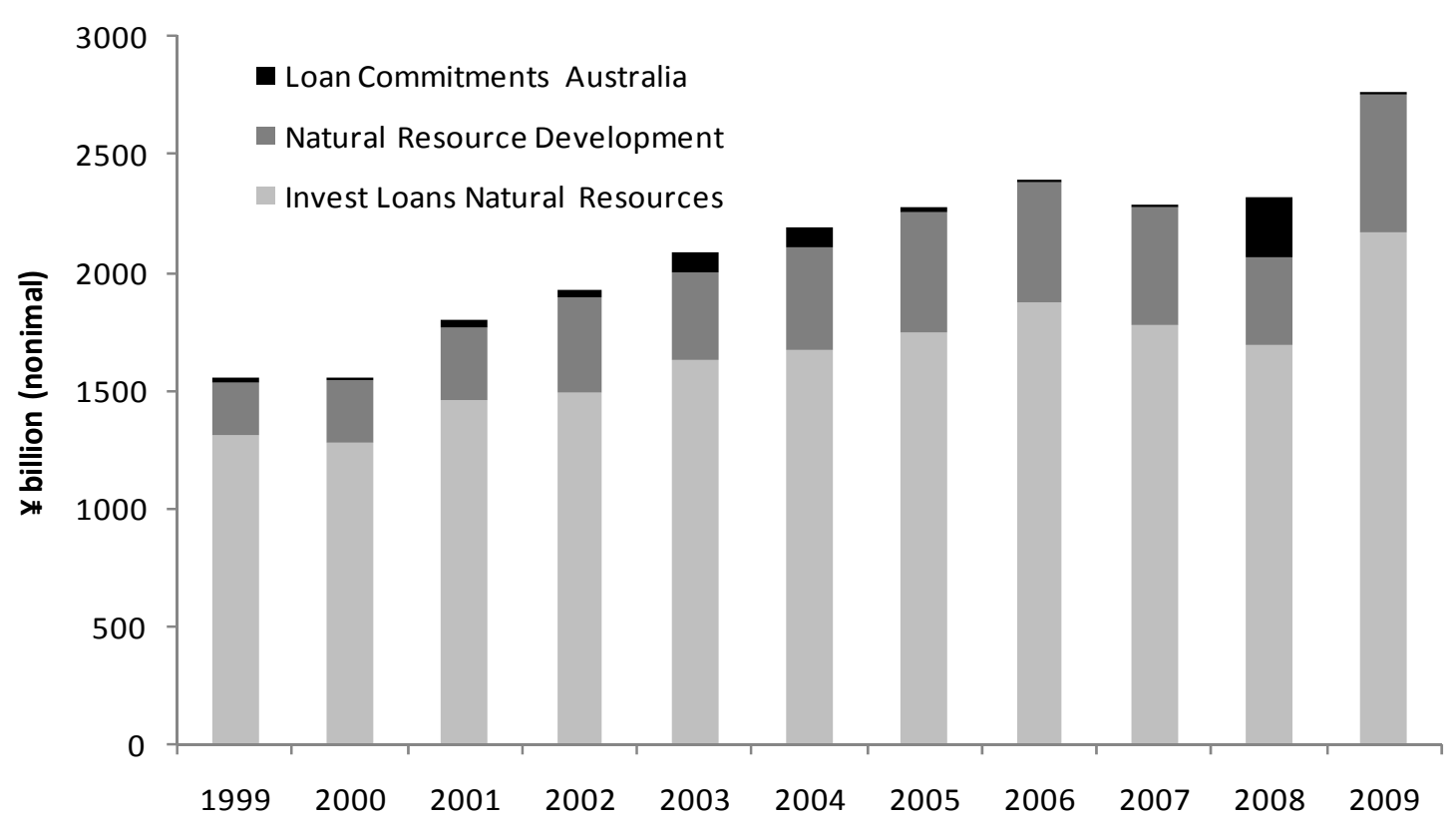

Figure 2. JBIC loan commitment to Australia, global natural resource development and global investment loans for natural resources in $¥$ billion 1999-2010

Source: Japanese Bank for International Cooperation Financial Reports FY99 - FY09

Further evidence of this trend is shown in Table 2. Natural resource funding commitments from JBIC have increased to over 25 percent of total commitments during the period 2001-09 while funding and guarantees made available to coal mining activities has declined from over 7 percent to around 2 percent as a proportion of natural resource funding. Over the period 2007-2009 JBIC invested in three coal mines globally for an amount less than $¥ 15 \mathrm{bn}$ (US\$200m). This level of funding would be insufficient to fund the development of a small coal mine in Australia, let alone be significant enough to create excess supply resulting in depressed prices.

Table 2. Natural resource loans by item (units: billions of yen, \%)

\begin{tabular}{lcccccc}
\hline & FY2008 & FY2009 & & & & \\
\cline { 2 - 7 } & Number & Total & Share & Number & Total & Share \\
\hline Energy Resources & 12 & 677.3 & 74 & 12 & 426.1 & 80 \\
$\quad$ Petroleum & 2 & 20.9 & 2 & 4 & 108.9 & 21 \\
Natural Gas & 6 & 641.6 & 71 & 4 & 294.4 & 55 \\
Coal & 2 & 6.8 & 1 & 1 & 8.2 & 2 \\
Uranium & 2 & 7.8 & 1 & 3 & 14.5 & 3 \\
Other Resources & 21 & 232.0 & 26 & 5 & 104.9 & 20 \\
Iron Ore & 7 & 150.5 & 17 & - & - & - \\
Copper Ore and Concentrate & - & - & - & 3 & 104.8 & 20 \\
Nickel & 1 & 42.4 & 5 & - & - & - \\
Aluminium and Bauxite & 4 & 14.7 & 2 & - & - & - \\
Wood, Wood Chips and Pulp & 6 & 11.1 & 1 & 2 & 0.1 & 0 \\
$\quad$ Other Metals & 3 & 13.1 & 1 & - & - & - \\
\hline Total & 33 & 909.3 & 100 & 17 & 531.1 & 100 \\
\hline
\end{tabular}

Source: Japan Financial Report 2010 
JBIC overseas investment assistance in the form of loans, investments and guarantees have grown from $¥ 523.7 \mathrm{bn}$ (43 percent of total commitment) in 1999 to $¥ 2,193.7 \mathrm{bn}$ in 2009 (65 percent of total commitment). For natural resources development in Australia the outstanding total of funds increased from $¥ 1,135.2 \mathrm{bn}$ in 1999 to $¥ 1,645.4 \mathrm{bn}$ in 2009 . It is clear that while the absolute level of funding for Japanese projects has increased in absolute terms, the amount made available for foreign coal mining activities of Japanese-based firms has dramatically decreased since the 1990s. Furthermore no significant financial assistance from JBIC has been invested in Australian coal assets over the period 2004-2010.

Table 3 illustrates that funding available for natural resource development and overseas investment loans represents around 25 percent of the total commitment made by JBIC in 2009, which has increased from around 14 percent of the total ten years previous. The growth from 1999 to 2009 has been gradual. So funds available for natural resources have increased in both absolute and relative terms however much of the more recent investments has been in oil, natural gas and iron ore. However over the same period Japan has not significantly decreased its consumption of coking or thermal coal so the conclusion reached in Colley (1997) and Koerner (1998) that the deployment of concessional Government-backed funding for the quasi-integration of Japanese trading companies to depress coal prices has not been a major strategy element since 1999 .

Table 3. Outstanding liabilities by purpose of financing (units: billions of yen, \%)

\begin{tabular}{lrrrc}
\hline & \multicolumn{2}{c}{ FY1999 } & \multicolumn{2}{c}{ FY2009 } \\
\cline { 2 - 5 } & Total & Share & \multicolumn{1}{c}{ Total } & Share \\
\hline Export Loans & $1,666.2$ & 14 & 808.2 & 7 \\
$\quad$ Shipping & 14.2 & 0 & 73.7 & 1 \\
Plant & $1,612.1$ & 14 & 732.7 & 7 \\
$\quad$ Technical Service & 39.9 & 0 & 1.8 & 0 \\
Import Loans & 740.3 & 6 & 793.2 & 7 \\
$\quad$ Natural Resource Development & 237.9 & 2 & 590.4 & 5 \\
$\quad$ Manufactured Goods and Technologies & 502.4 & 4 & 202.8 & 2 \\
Overseas Investment Loans & $4,613.8$ & 40 & $5,786.3$ & 54 \\
$\quad$ Natural Resources & $1,333.0$ & 12 & $2,182.8$ & 20 \\
$\quad$ Others & $3,280.8$ & 28 & $3,603.5$ & 33 \\
Untied Loans & $4,059.2$ & 35 & $1,333.9$ & 12 \\
Governmental Loans & 137.3 & 1 & 51.9 & 0 \\
Guarantees & 342.5 & 3 & $1,977.0$ & 18 \\
Equity Participations & 1.1 & 0 & 44.2 & 0 \\
\hline Total & $11,560.8$ & 100 & $10,795.1$ & 100 \\
\hline
\end{tabular}

Source: Japanese Bank for International Cooperation Financial Reports FY1999 and FY2010

This data indicates that the decline in funding coal mining investments in Australia occurred prior to the commodity price boom in 2007-08. Seaborne coal prices remained relatively low during the period 2000-04 with profitability levels increasing over the period 2004 to 2007. Coal asset profitability over the period 2007-2010 has significantly increased which has renewed global investment interest in Australian coal assets. The increased levels of investment from Japanese trading companies and the lack of JBIC participation over 1999-2010 appear to be aimed at seeking greater investment returns in contrast to the 1990s strategy of securing excess supply to depress prices.

Over 2005-2010 a significant proportion of Australian subsidiaries have actually secured loans in the Australian capital market for the investment in and ownership of coal mining assets, with limited or no recourse for security guarantees to the Japanese parent. This represents a clear shift in the funding practice of Japanese trading companies away from obtaining concessional loans or guarantees through the JBIC entity. 


\subsection{Profitability of Australian Coal Assets}

The Australian subsidiaries of Japanese trading companies have experienced profitability levels that greatly exceed those of their parent from 2005-2010. The following analysis demonstrates the level of profitability as measured using both return on assets (ROA) and return on equity (ROE). The Australian subsidiaries of the main Japanese trading companies are funded with both parent-guaranteed debt and equity and so the capital structure of the incorporated entities is not always clear. However uncertainty around the actual degree of financial leverage in the balance sheet can be overcome by comparing both ROA and ROE of the subsidiary and the parent. The uncertainty around the leverage implicit in the ROE measure does not affect the ROA measure.

ROA is an indicator of how profitable a company is before leverage is considered and is comprised of profit margin and asset turnover. Since the figure for total assets of the company depends on the carrying value of the assets, some caution is required for companies whose carrying value may not correspond to the actual market value. For resource companies operating in Australia, ROA is a reasonable initial estimate for performance benchmarking because the majority of their assets will have a carrying value that is close to their actual market value. Resources companies are very asset-intensive businesses which typically exhibit relatively low ROA, which nevertheless can be estimated accurately. In contrast ROE measures the rate of return on the level of ownership interest (shareholder equity) in the firm. ROE is also equivalent to the product of ROA and the degree of financial leverage employed by the firm as measured by the ratio of assets against shareholder equity. ROE generally indicates the capability of a business to generate cash internally. The degree of leverage across Japanese-based companies in Australia varies significantly which will clearly distort the ROE measure for comparisons in the industry hence the inclusion of ROA in this analysis.

Table 4 demonstrates that the ROA and ROE achieved by Australian-based Japanese trading companies are on average slightly less than the industry average over the period 2005-2010. The industry average is assumed to be the average of the producing coal companies that comprise the S\&P/ASX 200 Resources Index. However the Japanese companies who have significant capital invested in Australia such as Mitsubishi and Mitsui are earning returns on par with the industry average. Moreover each company has earned ROA and ROE in excess of their respective parent over 2005-2010. Average ROA for both the Japanese trading companies and their Australian subsidiaries in the ten years prior to 1997 was around 3 percent.

Table 4. Comparison of ROA and ROE for major Australian-based Japanese trading companies with their respective parent company averaged over FY2005-FY2010

\begin{tabular}{lcccc}
\hline \multirow{2}{*}{ Company } & \multicolumn{2}{c}{ Australian subsidiary } & \multicolumn{2}{c}{ Parent } \\
\cline { 2 - 5 } & ROA (\%) & ROE (\%) & ROA (\%) & ROE (\%) \\
\hline Mitsubishi Corp & 14.34 & 26.26 & 4.05 & 13.88 \\
Mitsui \& Co. & 13.48 & 20.77 & 2.07 & 13.11 \\
Marubeni & 5.67 & 24.33 & 2.34 & 16.26 \\
Sumitomo & 5.98 & 20.42 & 2.70 & 14.08 \\
Idemitsu Kosan & 7.37 & 8.01 & 3.01 & 3.27 \\
Itochu & 8.93 & 13.77 & 2.34 & 9.54 \\
Sojitz & 12.11 & 24.91 & 1.51 & 9.12 \\
S\&P/ASX 200 Resources average & 14.44 & 25.70 & N/a & N/a \\
(coal companies) & & & & \\
\hline
\end{tabular}

There appears to have been a sizeable shift in coal mining returns expectations of the parent companies of their Australian subsidiaries from those that existed over 1970-1997 as raised by Colley (1997) and Koerner (1998). In the 1970s Yonezawa (1978) first argued that Japanese trading companies pursued national interest objectives in procuring raw materials at a cost that exceeded the benefits of achieving the lowest price possible, and Colley (1997) showed that low profitability in the coal mining sector still exceeded the average returns earned by their respective parent companies. The above evidence shows that on the basis of ROA and ROE measures, the focus on low profitability for the purpose of achieving below average prices and volume stability has changed to seek above average returns while retaining coal sector information advantages. The value of such information advantages in achieving lower contract prices will now be examined. 


\section{Information Advantages and Price Negotiation}

As part of this analysis we also wish to determine if the significant investment of the Japanese trading companies has led to below average coal supply agreement prices and volume stability through any information advantages associated with ownership. Thermal coal sales data from January 2008 to June 2009 was obtained from three Australian coal mining companies who have varying degrees of Japanese equity ownership. The differential in the FOB offtake price to the FOB Newcastle benchmark price was computed for each shipment after adjusting for the quality differences in ash, moisture and sulphur for each contract. Figure 3 illustrates the differentials for individual shipments made to non-Japanese Asian-based trading firms. Total shipment volume over this period was 4.48 million tonnes. The average differential over the period was -US\$2.48 per tonne meaning that a strong discount was achieved over the period and from Figure 3, no persistent change in the level of the discount is evident.

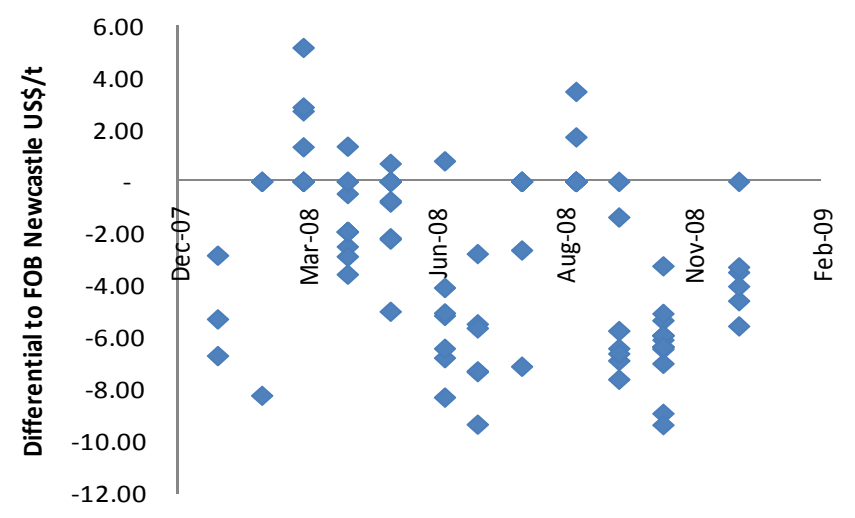

Figure 3. Non-Japanese Asian-based trading company premium/discounts to FOB Newcastle benchmark price 2008-09

Source: McCloskey Coal, GlobalCOAL

Figure 4 illustrates the differentials for individual shipments made to Japanese trading companies. Total shipment volume over this period was 4.1 million tonnes. The average differential over the period was -US\$1.53 per tonne meaning that while a strong discount was achieved over the period, it was significantly less than the non-Japanese Asian-based trading firms and often the benchmark price itself was achieved. The variation in sales price data is not significantly different between the two series, nor is there significant variation in the timing of the shipments themselves. This is formally tested below.

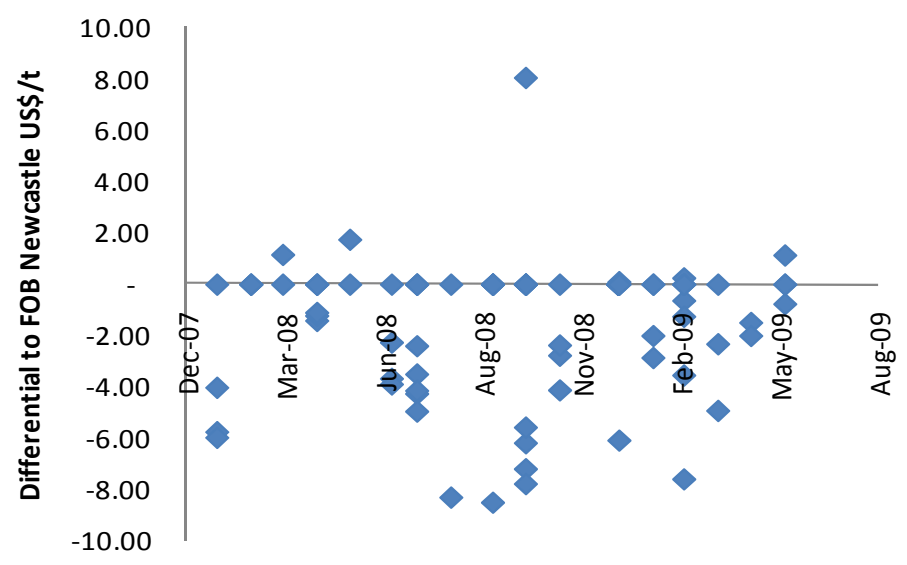

Figure 4. Japan-based trading company premium/discounts to FOB Newcastle benchmark price 2008-09 
To test for volume stability we conduct a simple distribution analysis of each time series. Figure 5 illustrates the q-q plot for coal price differentials to the FOB Newcastle benchmark in US\$/t for non-Japanese Asian-based trading companies. A q-q plot is a graphical method for comparing the distribution of the differentials against a normal distribution. If the volume of coal shipments were unstable over the period then we would expect to see price differentials skew away from the mean differential value, as coal consumers would look to buy coal at a much higher discount than normal, translating into significant outliers in the data. Stable coal volumes should be associated with normally distributed differences in the price differential with few outliers.

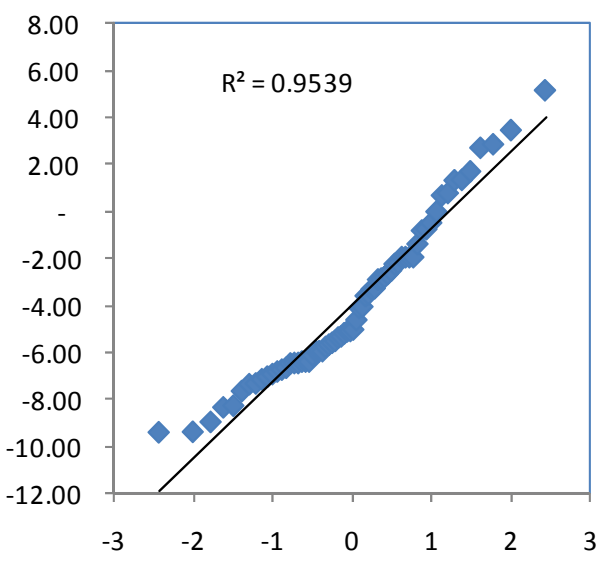

Figure 5. Normal q-q plot of non-Japanese Asian-based trading company premium/discounts to FOB Newcastle benchmark price 2008-09

The coal prices of each series have been adjusted for the quality characteristic differences of ash, moisture and sulphur. The relatively linear slope of the q-q plot along with the $\mathrm{R}^{2}$ value of 0.9539 indicates that there is little dispersion of values from normally distributed prices and therefore relatively steady offtake volumes over the period.

Figure 6 illustrates the $\mathrm{q}-\mathrm{q}$ plot for coal price differentials to the FOB Newcastle benchmark in US\$/t for Japanese trading companies. The relatively linear slope of the $\mathrm{q}-\mathrm{q}$ plot along with the $\mathrm{R}^{2}$ value of 0.9889 indicates that there is even less dispersion of values from normally distributed prices than non-Japanese Asian-based trading companies and therefore very steady offtake volumes.

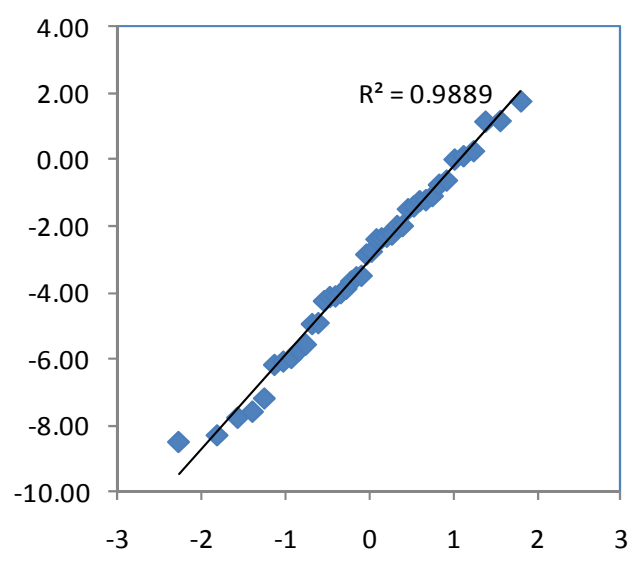

Figure 6. Normal q-q plot of Japanese trading company premium/discounts to FOB Newcastle benchmark price 2008-09 
Table 5 provides the descriptive statistics for both distributions. Both sets of data have similar distributional characteristics and therefore there appears to be little information advantage obtained by Japanese trading companies in thermal coal price negotiation.

Table 5. Descriptive statistics of premium/discounts to FOB Newcastle benchmark price for non-Japanese Asian based trading company and Japanese trading companies 2008-2009

\begin{tabular}{lcc}
\hline & $\begin{array}{c}\text { Non-Japanese trading } \\
\text { companies }\end{array}$ & $\begin{array}{c}\text { Japanese trading } \\
\text { companies }\end{array}$ \\
\hline Mean & -2.48 & -1.53 \\
Standard Error & 0.32 & 0.30 \\
Median & -1.65 & 0.00 \\
Mode & 0.00 & 0.00 \\
Standard deviation & 3.34 & 3.17 \\
Sample variance & 11.15 & 10.11 \\
Kurtosis & -0.13 & 2.21 \\
Skewness & 0.68 & 0.76 \\
Range & 14.51 & 16.56 \\
Minimum & -9.36 & -8.50 \\
Maximum & 5.15 & 8.06 \\
Confidence level (5\%) & 0.82 & 0.60 \\
\hline
\end{tabular}

The further illustrate the inability to take advantage of coal production cost information in negotiating discounts to the benchmark price, the actual contracted volumes and price differentials for both non-Japanese Asian based trading companies and Japanese trading companies were plotted. Figure 7 shows the differentials and volumes of the non-Japanese traders who largely accept the market price of the day. There appears to be no relationship between contracted volume and price indicating that their ability to contract at a larger discount does not necessarily correlate with larger volumes.

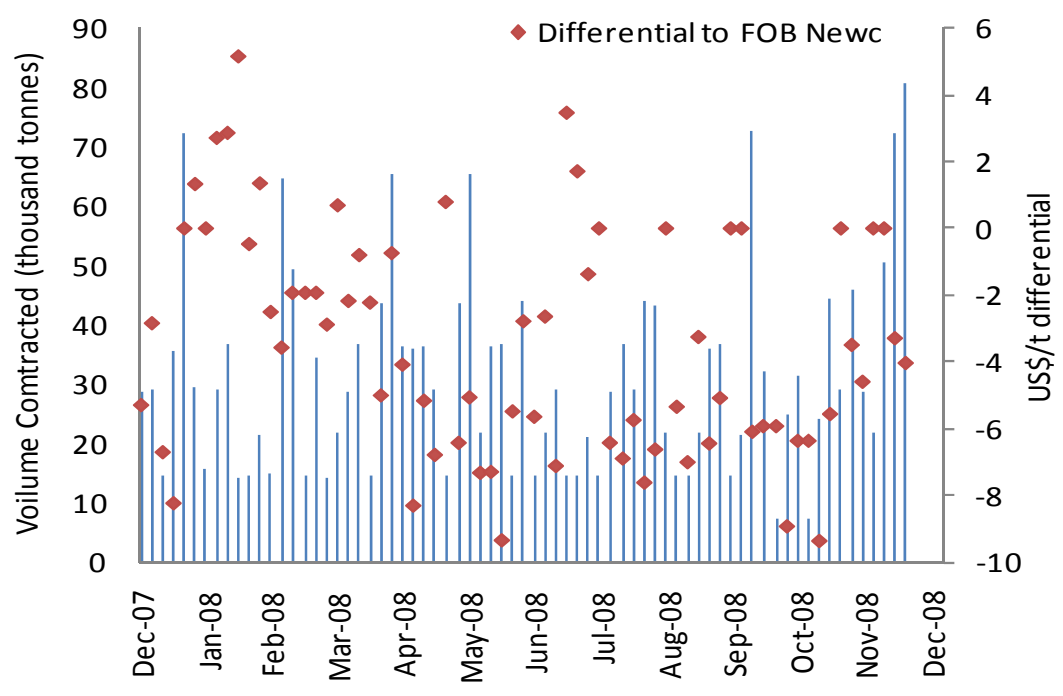

Figure 7. Volume and price differential plot of non-Japanese Asian based trading company premium/discounts to FOB Newcastle benchmark price 2008

Source: BHP Billiton, Cargill 
Similarly Figure 8 also shows that there is no persistent relationship between contracted volume and price for Japanese trading companies indicating that their ability to contract at a larger discount does not correlate with larger volumes either.

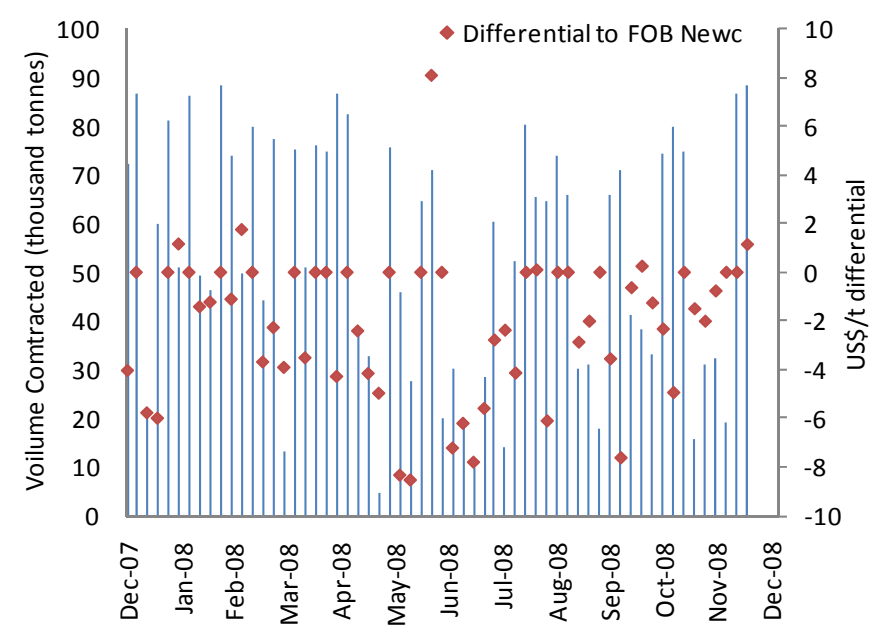

Figure 8. Volume and price differential plot of Japanese trading company premium/discounts to FOB Newcastle benchmark price 2008

Source: BHP Billiton, Cargill

This result highlights that even if information advantages exist for Japanese investors in Australian coal mining assets no persistent advantage is evident in coal price negotiation outcomes nor is there any advantage taken by the investors in the timing of shipments themselves. Hence lower prices and volume stability are not significant benefits from Japanese equity ownership in coal assets.

\section{Non-Japanese Foreign Investors}

It was claimed in Colley (1997) that the number of Japanese investors in the Australian coal industry was not necessarily a wave of substantial investment from a Japanese investors' point of view but rather a small strategic investment undertaken by a number of Japanese companies as part of a consensus view on managing coal production and capacity. From the above analysis as commodity prices have increased over 1997-2010 the assumed aims of equity investment to achieve lower prices and volume stability through information asymmetry have been exchanged for above average capital returns for the parent company with no real loss of control on offtake volume.

Table 6. Comparison of ROA and ROE for major Australian-based foreign trading companies by country with their respective parent companies averaged over FY2005-FY2010 (where data is unavailable for the full five year period all available data is used)

\begin{tabular}{lccrc}
\hline & \multicolumn{2}{c}{ Australian subsidiary } & \multicolumn{2}{c}{ Parent } \\
\cline { 2 - 5 } & ROA $(\%)$ & ROE $(\%)$ & ROA (\%) & ROE (\%) \\
\hline Korea & 12.11 & 24.91 & 10.15 & 15.29 \\
China & 12.01 & 22.81 & 6.40 & 13.37 \\
India & -1.00 & -2.25 & 4.65 & 12.89 \\
USA & 19.87 & 43.07 & 7.26 & 17.79 \\
Brazil & 13.34 & 22.75 & 12.52 & 30.27 \\
Japan & 9.69 & 19.78 & 2.57 & 11.32 \\
S\&P/ASX 200 Resources & 14.44 & 25.70 & N/a & N/a \\
average (coal companies) & & & & \\
\hline
\end{tabular}


It is prudent to examine the investment behaviour and motives of other new entrants in the Australian coal market from South Korea, China and India, as well as existing participants from the US and Brazil. In particular we wish to determine if the advantages associated with equity ownership serve as the main motive behind their acquisition strategies, or if other reasons such as the security of supply are driving foreign investment in coal mining. Table 6 provides a comparison of ROA and ROE for major Australian-based foreign trading companies by country with their respective parent companies averaged over FY2005-FY2010. Where data is unavailable for the full five year period all available data is used.

Korean investment patterns in Australia have changed since 2005. Korean investment in Australia has been based on a strategy of obtaining a stable supply of coal for the long term. Existing investments undertaken by Korean companies have typically been small strategic equity positions (10-15 percent at most) linked to marketing rights, however some recent investments have been larger with majority ownership positions including operating rights being established. The Wallarah 2 Coal Project near Wyong NSW is an underground thermal coal mine that is 100 percent owned by the government-backed Korea Resources Corporation (KORES). In 2007 the Korean Government implemented a plan for foreign natural resource developments and one of the main elements is to grow the country's self-sufficiency ratios for key mineral resources including bituminous coal from 41 percent in 2008 to 50 percent by 2016. Table 6 illustrates that average investor returns of the Australian subsidiaries are likely to exceed the average returns to the parent however security of supply remains the stated aim of Korea's foreign investment aims under KORES. No private companies are likely to receive the backing of the Korean Government for concessional funding since KORES will be the primary vehicle for government-sponsored foreign investment to achieve the self-sufficiency ratios. Pohang Iron and Steel Company (POSCO) is the largest private Korean investor in Australian coal mines however they obtain funding from the usual channels in the capital market.

The newfound confidence in investing in direct ownership and operating rights is an approach emulated by recent Chinese investments, particularly the acquisition of Watermark, Felix Resources and the Austar mine in the Hunter Valley by Chinese companies. Thus far the Chinese companies have funded purchases of Australian coal assets using cash reserves and the need for concessional funding from government agencies in the future is expected to remain low. It is expected that in contrast to Korean and Indian investors, security of supply is not the primary objective behind Chinese investment in Australian coal assets as these represent a very small portion of total Chinese coal consumption (less than 0.04 percent). Some Chinese coal companies also maintain majority ownership of Australian domestic electricity assets which indicates a normal strategy aimed towards achieving superior investment returns for Chinese investors, rather than securing supply of thermal and coking coal.

Indian investors first acquired sizeable interests in operating assets in 2007 with more investments in reserves and infrastructure opportunities observed in 2010. Historical investment returns in Australian assets have been comparatively low and the trend towards investing in developing assets indicates that security of supply is the primary objective. For major Indian power producers Government approvals for plant construction are often conditional on securing a certain volume of imported bituminous coal so the motive behind the acquisition of coal assets in Australia is expected to be for the security of supply rather than investment returns.

\section{Concluding Remarks}

The assertion that financing and investment practices by the Japanese Government and Japanese coal consumers in the Australian coal industry are aimed at stimulating supply to the point where oversupply is significant enough to affect prices seen in the 1990s has clearly not been the primary strategy over the past 10-15 years. While significant evidence to support investment practices influencing a persistent oversupply of coal is apparent in previous studies such as Anderson (1987) and Colley (1997), the capacity of Japanese trading companies to influence prices through supply and use information advantages of marginal production costs in contract negotiations has diminished over the period 1997-2010. At the same time the Japanese trading companies have experienced significant returns as measured by the metrics of return on assets and return on equity observed in a number of Australian subsidiaries. Moreover the established Japanese trading companies have clearly shifted from minority to majority ownership and in some cases have sought outright ownership in both existing and newly developing coal mines in Australia. In 2009-10 several Japanese companies have obtained limited or no recourse to parent security or guarantees for a range of coal asset investments, and have instead turned to the local capital market for financing rather than rely on concessional funding from JBIC.

This study has examined the major types of investment practices by Japanese trading companies in the form of concessional finance and debt guarantees supplied by JBIC for investing in the Australian coal industry. Where the profitability of Japanese investments in Australia was poor in the 1990s more recent experience has shown 
that returns over the period 1997-2010 have exceeded their parent company returns and are reasonable when benchmarked against their Australian peers. The experience of low profitability driven through a strategy to simultaneously secure supply and reduce prices has not carried over during the commodity price boom and the quasi-integration strategy employed in the 1990s is unlikely to emerge again. Japan continues to import significant volumes of both coking and thermal coal and is now seeking long term coal supply agreements in a more competitive global coal market. Japanese trading companies investing in Australian coal assets are also now competing with Chinese, Korean and Indian trading companies looking to secure supply. Profitability is seen as a key element of the new investment paradigm and may spill over to other raw material acquisitions by the major Japanese trading companies in the future.

\section{References}

Anderson, D. (1987). An analysis of Japanese coking coal procurement policies: The Canadian and Australian experience. Centre for Resource Studies, Queens University, Kingston, Ontario.

Australia-Japan Economic Institute. (1996). Economic Bulletin, 4(9).

Australian Bureau of Statistics. (2010). 5625.0 Private New Capital Expenditure and Expected Expenditure, Australia, September. Retrieved from http://www.abs.gov.au/ausstats/abs@.nsf/products/C663DEB965257495CA257679000FA4A6?OpenDocu ment

Barnett, D. W. (1994). Australia's coal industry: Fuel for growth. Energy Policy, 22(4), 353-367. http://dx.doi.org/10.1016/0301-4215(94)90009-4

Colley, P. (1997). Investment practices in Australian coal: The practice and profit of quasi-integration in the $\begin{array}{lllll}\text { Australia-Japan coal trade. Energy } & \text { Policy, }\end{array}$ http://dx.doi.org/10.1016/S0301-4215(97)00128-6

D'Cruz, J. R. (1983). Quasi Integration Strategies in Markets for Industrial Raw Materials. Faculty of Management Studies, 83(4). University of Toronto, Canada.

Dowling, G. (1987). Buying is marketing too - Japan's influence on the Australian coal trade. Long Range Planning, 20, 35-43. http://dx.doi.org/10.1016/0024-6301(87)90030-6

International Energy Agency IEA. (2009). World Energy Outlook. France: International Energy Agency Publications.

Koerner, R. (1993). The behaviour of Pacific metallurgical coal markets: the impact of Japan's acquisition strategy on market price. Resources Policy, 19(1), 66-79. http://dx.doi.org/10.1016/0301-4207(93)90053-P

Koerner, R., Rutledge, I., \& Wright, P. (1995). The impact of oil company investment on the world coal industry: overcapacity and price destabilisation 1973-1992. Energy Policy, 23, 659-667. http://dx.doi.org/10.1016/0301-4215(95)00064-P

Koerner, R. (1998). The influence of sogo shosha companies on contract bargaining in the Pacific metallurgical coal trade. Resources Policy, 24(3), 167-177. http://dx.doi.org/10.1016/S0301-4207(98)00030-0

McIntosh Baring. (1993). Australian Coal Industry Study. Melbourne: McIntosh and Co. Ltd.

Roehl, T. (1983). A transactions cost approach to international trading structures: the case of the Japanese general trading companies. Hitosubashi Journal of Economics, 24, 119-135. http://hermes-ir.lib.hit-u.ac.jp/rs/handle/10086/7920

Swan, A., Thorpe, S., \& Hogan, L. (1999). Australia-Japan coking coal trade: A hedonic analysis under benchmark and fair treatment pricing. Resources Policy, 25, 15-25. http://dx.doi.org/10.1016/S0301-4207(99)00004-5

Willacy, B., Griffin, R., \& Middleton, V. (2010). Australia: Coal exploration exploding in Queensland. Wood Mackenzie Coal Supply Service Insight.

Yonezawa, Y. (1978). Resource trade and economic security: the case of coal. In Drysdale, P., \& Kojima, K., (eds.), Australia-Japan economic relations in the international context: recent experience and the projects ahead. Canberra: Australia-Japan Economic Research Project. 